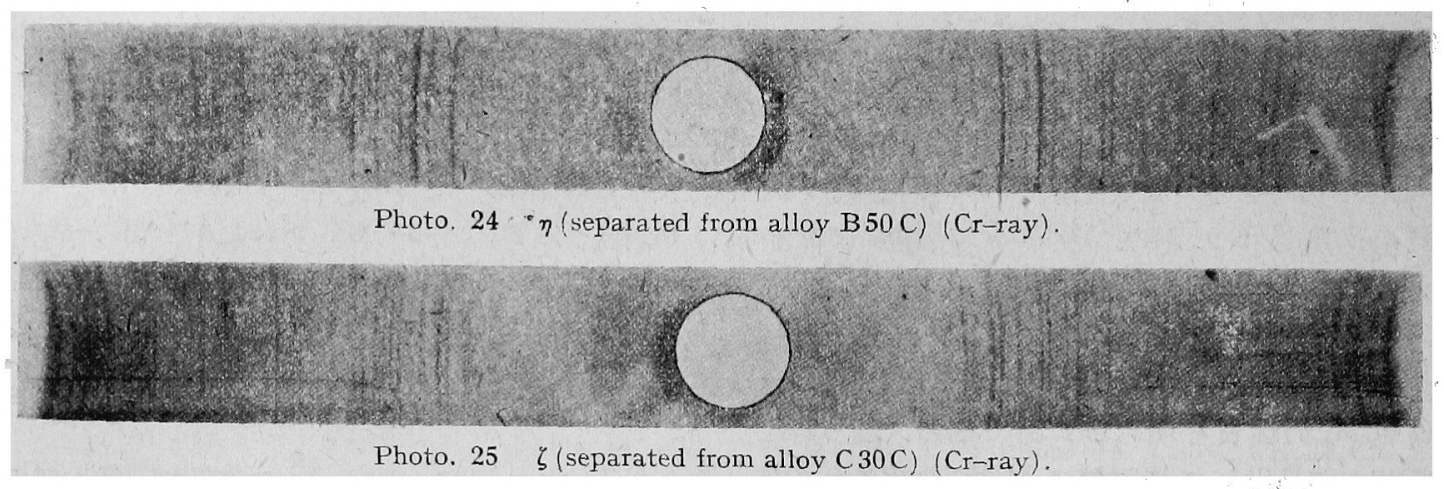

は夫« $69.96 \%$ Cr 及び 79.37\%Cr であつた，てれに よつて Cr 炭化物は相當量の Ni を固溶するもので, Fig. 4 に於ける $\zeta_{4}$ 點怯約 $70 \% \mathrm{Cr}, \eta_{2}$ 點は約 $80 \% \mathrm{Cr}$ に存在 する事を知つた。

\section{VIII. 總括}

1. $\mathrm{Ni}-\mathrm{Cr}-\mathrm{C}$ 三元系合金》全系江亘つて, 熱分析及び 㙷微镜試驗を行ひ，Fig. 4 亿示す如さ状態圖を決定した。

2. 本系には三元化合物を生ぜず，固態に於いては $\gamma$ 相 ( $\mathrm{Ni}$ 固溶體)， $\alpha$ 相 ( $\mathrm{Cr}$ 固溶體)，照鉛 $(\mathrm{G})$ 並びそ 4 種の $\mathrm{Cr}$ 炭化物 $\varepsilon, \eta, \zeta, \kappa か ゙$ 存在する.

3. 本系には次の不變系反應が仔在する。 (a) 融體 $\left(M_{1}\right) \rightleftarrows \alpha+\gamma+\varepsilon$

(b) 融體 $\left(\mathrm{M}_{2}\right)+\eta \rightleftarrows \gamma+\varepsilon$

$\left(1305^{\circ}\right)$

(c) 融體 $\left(M_{3}\right)+\eta \rightleftarrows \gamma+\zeta$

(d) 融體 $\left(M_{4}\right) \rightleftarrows \gamma+\mathrm{G}+\zeta$

(e) 融體 $\left(\mathrm{M}_{5}\right)+\kappa \rightleftarrows G+\zeta$

4. $\mathrm{Ni}$ の磁氣變態點は, $\mathrm{Cr}$ 及び C が同時に固溶する 事によつて單獨に固溶する場合より一層急激に溫度を降 下する。

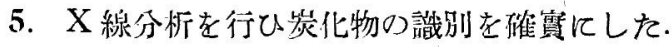

終りに踇み $\mathrm{X}$ 線試驗によつて炭化物の制別に多大の 御助力を與へられた大澤睢士並びに同研究室諸賢に對し 深毕なる謝意を表する次第である。

\title{
$\mathrm{Cu}-\mathrm{Si}$ 系 $\boldsymbol{\kappa}$ 相の共析變態に就て
}

\section{高 本 信 次 郎*}

Nobujirô Takamoto: Confirmation of $\alpha+\gamma$ Eutectoid in Cu-Si System. By microscopic examsnation the domain of the new $\kappa$ phase adjacent to $\alpha$ in the $\mathrm{Cu}-\mathrm{Si}$ system is determined. The $\kappa$ phase decomposes at $555^{\circ}$ into $a+y$ on drastic annealing and, the eutectoid composition is $5.13 \%$ Si. The decomposition below $555^{\circ}$ is extremely slow unless the samples are cold-worked. Therefore to determine the solubility curve of $\gamma$ to $a$ solid solution, the specimens should be annealed at least for 7 days aiter the cold-working

(Received February 25, 1940)

$\mathrm{Cu}-\mathrm{Si}$ 系の狀態圖に就ては最近伊澤氏(1) が新相 $\kappa$ を 發見せられて從本力狀態圖江重大极訂正を加へられた が，筆者仙數年來 $\mathrm{Cu}-\mathrm{Mn}-\mathrm{Si}$ 合金つ研究を進为つ」ある

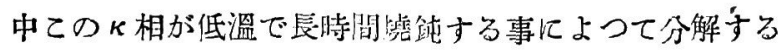
事索認め, $\mathrm{Cu}-\mathrm{Si}$ 二元系儿就て顯微筧的儿再吟味を行つ たからその結果老簡單に報告し度いと思ふ。

$\kappa$ 相の分解汇關しては既に伊澤氏女之を認められて異

* 東北帝國大學工學部金屬工學科

（1）伊澤，日本金愿學會誌，2(1938)，400.
几提出せられを抄態圖わ一部訂正し度いと本誌第2 笑第 2 號》寄畫に述へて居られるが，この變化の本質並

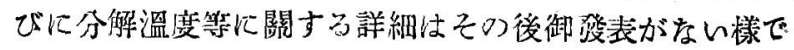
ある。

極めて最近 C. S. Smith ${ }^{(2)}$ 及び A. G. H. Andersen ${ }^{(3)}$

(2) C. S. Smith, Metals Techn. A. I. M. E., 6(1939), No. 4.

(3) A. G. H. Andersen, Metals Techn. A. I. M. E., B (1939), No. 7 . 
の研笁が筂表されたがその結果を見ると筆省の場合之定 性的には殆ど一致して居る。

先づ實驗つ結果を總括して Fig. 1 に示して置いた.筆

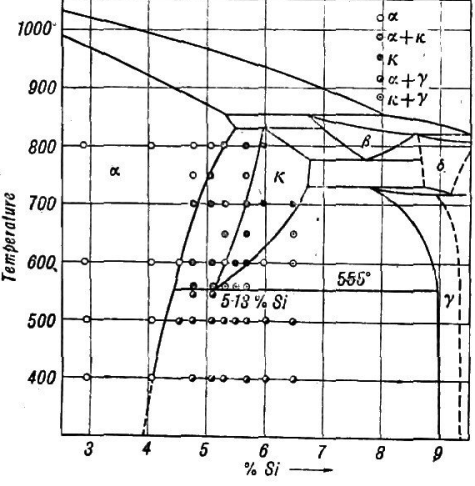

Fig.1 $\mathrm{Cu}-\mathrm{Si}$ Diagram. 者は主として 固溶體凹溶解度 曲線と $\kappa$ 相の存 在區域江就て專 ら顯微篭的江研 笁し, その他の 平衡關係を示す 曲線は伊澤氏の 結果を引用し た.

郎ち火相は $555^{\circ}$ 亿於て共 析變化を起して $\alpha+\gamma$ となり，その共析組成は Si $5.13 \%$ である事を確めたのである.

檢鏡に使用した試料は何れ女原料として棹銅と $99.0 \%$ の Metallic Silicon 配合し各 $200 \mathrm{~g}$ 徑 $30 \mathrm{~mm}$ の夕 ンマン管で熔製し，そのま〉葙灰中で緩冷した後約 $700^{\circ}$ の赤熱狀態で鍛造して徑 $15 \mathrm{~mm}$ の丸棒几仕上げ，一旦 冷却してから再び $700^{\circ}$ に加熱, 30 時間の燒鈍を行ひ，次 に之を輕く常溫錹鍊して徑 $12 \mathrm{~mm}$ の丸棒に仕上げを素 材から採づた。

Photo. 1〜11 は Si 含量と熱處理に上る顯微鏡組織の 變化を示したものである。師ち Photo. 1 はSi $4.62 \%$ 合金を $600^{\circ}$ に 168 時閒加熱した後水水中に燒入れたる ので $\alpha$ 單相から成り，同じ熱處理を施した Si $5 \cdot 70 \%$ 合 金は Photo. 2 に示寸通り $\kappa$ 單相加成々. $\alpha$ 之との 識別は相當困難ではあるが適當な試藥を朋ひればその简 蝕の度合上他調から區別する事が出來る。試彎としては 從來の $\mathrm{H}_{2} \mathrm{O}_{2}+\mathrm{NH}_{4} \mathrm{OH}$ 溶液飞適當量の $\mathrm{KOH}$ を添加 しをものが一番よい.

Photo. 3 は Si $5.13 \%$ 合金を $600^{\circ}$ 飞 168 時間加熱 しを後水水中に燒入れた場合で之は $\alpha+\nwarrow$ 澏域の典型的 な組織である。は $\alpha の$ 双晶面に沿つて首状に發達し所 謂Widmannstätten 組䋨を是するが，之は極めて安定な 組織で容易飞崩れない，例へば Photo. 5 はSi $5 \cdot 13 \%$ 合金を $800^{\circ} に 1$ 時間加熱した後炭火を埋めた菜灰中で

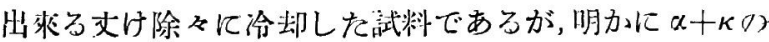

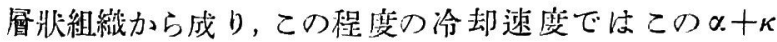
共存相が常に常溫まで持ち來される事を示して居る。

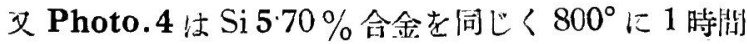
加熱後葬灰中で除冷したもので大部分は $\kappa$ 相であるが部 分的に $\alpha+\kappa$ の層狀組織が現はれてるる。乙れは朋かに 未だ本衡に達してるない證左で，且つ $\kappa$ 相も亦容易に常

溫まで持ち來す事が出來うことを示してるる。

然る几こ机らの試料老 $550^{\circ}$ 以下の低溫で約 1 避閏燒 鈘すればての層狀組織は完全几分解して全然遠つた組織 を現はす 即ち Photo. 6 はSi 5.13\% 合金を $400^{\circ} に$ 168 時開燒鈍した後水水中に燒入れたもので， 凤の地に

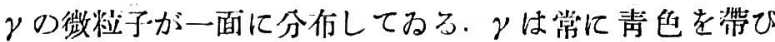

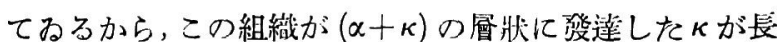
期の燒鈍によつて球狀化したものでない事は一見して明

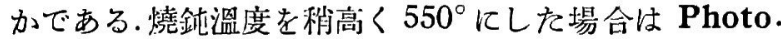
7 亿示す如く，大部分は $\alpha+\gamma$ の共析組織であつたが部 分的に $\alpha+\kappa の$ 層狀組織を現はした.

仍で一旦完全を.共析組織になつた Photo. 6 の試料を 折本して,これを $560^{\circ}$ に 144 時間燒鈍しを處 Photo. 8

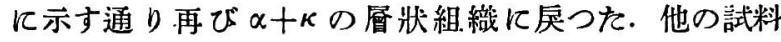
几就ても同樣の;結果を得たのでての共析變態の溫度は $555^{\circ}$ 附近であらうと推定する事が出來る。

次に Si含量が $4 \cdot 62 \%, 4 \cdot 80 \%, 5 \cdot 10 \%, 5 \cdot 13 \%, 5 \cdot 32 \%$, $5.40 \%, 5 \cdot 70 \%, 5.96 \%, 6.05 \%$ なる 9 種の試料依て 同樣の檢鏡を行ひ, ての共析點は Si $5.13 \%$ である事を 確めた. Photo. 6 はての共析組織である.Photo. 9 は Si $570 \%$ 合金を $400^{\circ}$ 飞 168 時間加熱しを後水水中に燒大 れたもので $(\kappa+\gamma)$ 區域で析出する初析の $\gamma$ が棒狀に現 はれ他は一面に典型的な $(\alpha+\gamma)$ 共析組織になつてるる。

Photo. 10 结Si $6.05 \%$ 合金飞同樣校熱處理を行つ て得を組織で明かに 澤氏の状態圖江從へば $\kappa$ 單相となるべき試料である。 唒 Photo. 11 は Si 5.96\% 合金を $800^{\circ}$ に 1 時間加熱し た後 $600^{\circ}$ まで爐中冷却し，ての溫度に 6 時間保つてから 水水中に燒入れた場合で $\gamma$ が火の㜔界に沿つて析出し， 明かに $(\kappa+\gamma)$ 區域である事を示す。ての組織为燒入れ するまでもなく相當綬慢に椧却しても容易に常溫まで持 ち來す事が出來る。

以上簡單ながら各區域の顯微鏡組繶によつて $に$ 相の 共析變態と $\alpha$ 固溶體の溶解度曲線在略将肋かにし得たと

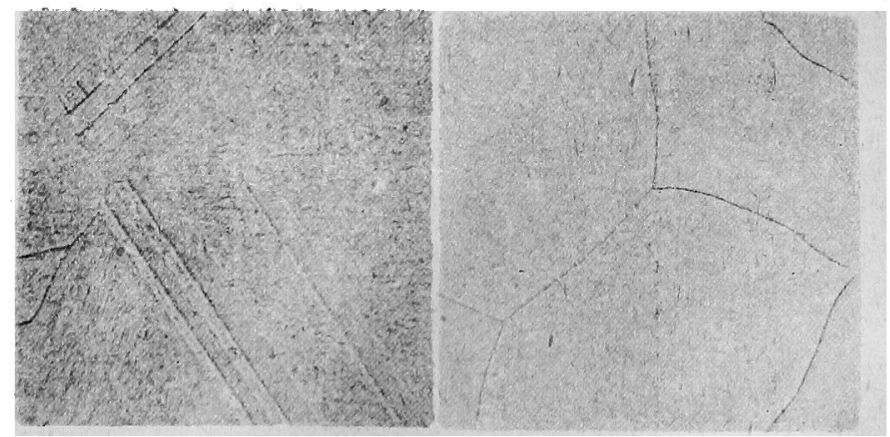

Photo. 1 Si $4.62 \%$ alloy, quenched after 169 hrs. annealing at $600^{\circ}$.

$\times 300$
Photo. 2 Si $5 \cdot 70 \%$ alloy, quenched after $168 \mathrm{hrs}$. annealing at $600^{\circ}$

$\times 300$ 
思ふ.

$\kappa$ 相の共析變化はその反應述度が意外に僬く，普通の 熱處理では常に高溫組織が常溫に於て認められるため， 從來の沘迷の因をなしてるた. 例へば $400^{\circ} の$ 燒鈍では少

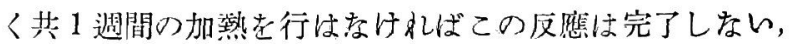
而も靚鈍前輕く常溫加工老加へて㯰く事が必要である.

Zn $15 \%$ を含さ所謂シルジン㒼銅が 350〜 500 の長期 加熱によつて著しい脆性を是する事は數年桃問題になつ こるろが,このた相の共析變態に基く $\gamma$ 相の析出がその 原因であららと信ずう。

$(\alpha+\kappa)$ の特翼な層狀組織に關しては C. S. Smith に
依礼ぱ、相と， 相とはその表面エネルギーが殆ど等しい ためめの面心立方格子の双晶面に秱密六方格子の 定的に介在して容易に球狀化しないるのと推定される。 $\mathrm{Cu}$ 上 $\mathrm{Si}$ 上の原子容が殆ど等しん事から面心汒方格子の 汇八面體の面と六方格子の底面とが潢い溫度範图に亘つ て又庴い組成船圍に亘つて事實上合致するであらう事は 哀易几想像法來る。

終りに本研究に齔し御愁篤をる御指導を賜つた濱任松 二鼿先生に厚く御禮明し上げると共に，實驗の遂行に當 り助力を惜しまれなかつた藤时道義君江感謝の意を裴し ます

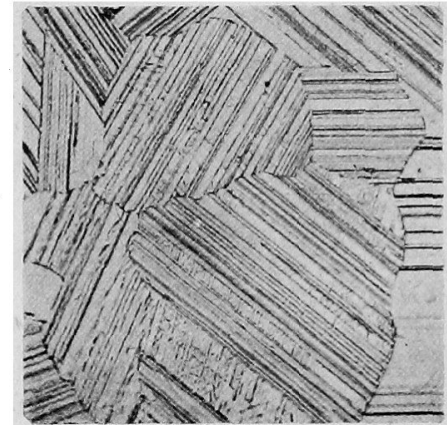

Photo. 3 Si $5 \cdot 13 \%$ alloy, quenched after $168 \mathrm{hrs}$. annealing at $600^{\circ}$. $a+\kappa$ $\times 300$

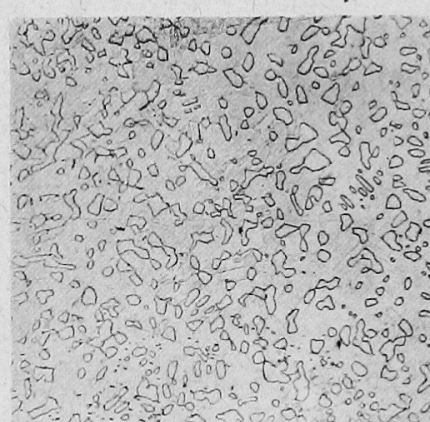

Photo. 6 Si $5 \cdot 13 \%$ alloy. quenched after $168 \mathrm{hrs}$ annealing at $400^{\circ}$ $a+\gamma$ $\times 300$

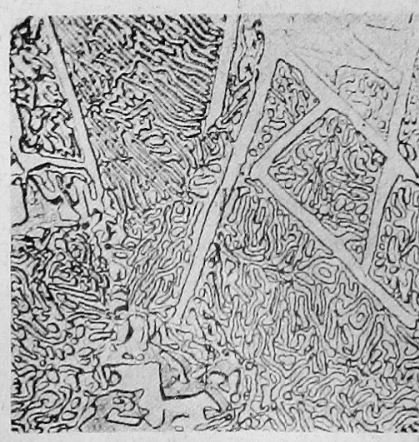

Photo. 9 Si $5 \cdot 70 \%$ alloy, quenched after $168 \mathrm{hrs}$. annealing ar $400^{\circ}$.

$a+\gamma$

$\times 300$

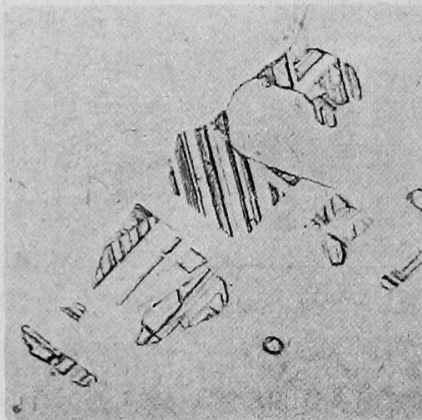

Photo. 4 Si $5 \cdot 70 \%$ alloy, very slowly cooled alter lhr. at $800^{\circ}$ Almost $\kappa$, partiy $a+\kappa . \quad \times 300$

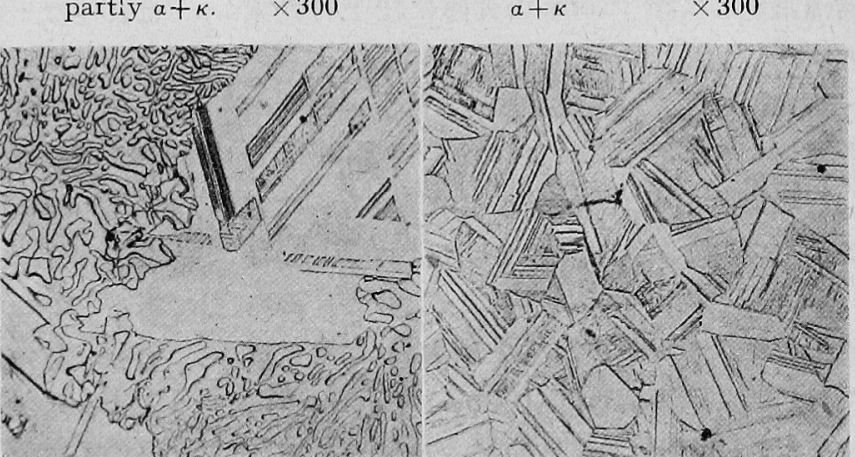

Photo. 7 Si $5 \cdot 13 \%$ alloy quenched aiter $144 \mathrm{hrs}$. annealing at $550^{\circ}$. Partly decomposed $a+\kappa \cdot \times 300$

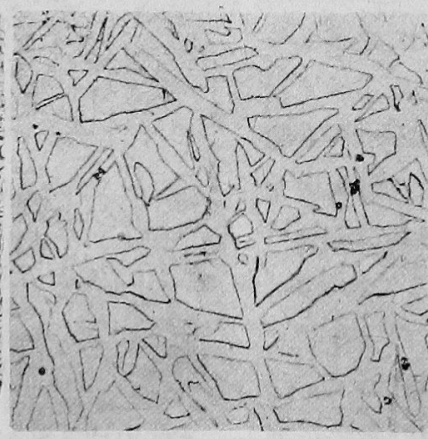

Photo. 10 Si $6.05 \%$ alloy, quenched after $168 \mathrm{hrs}$. annealing at $400^{\circ}$.

$a+\gamma$

$\times 300$
Photo. 8 The same specimen as Photo. 6 quenched after $144 \mathrm{hrs}$. reannealing at $560^{\circ}$ $\omega+\kappa$ $\times 300$

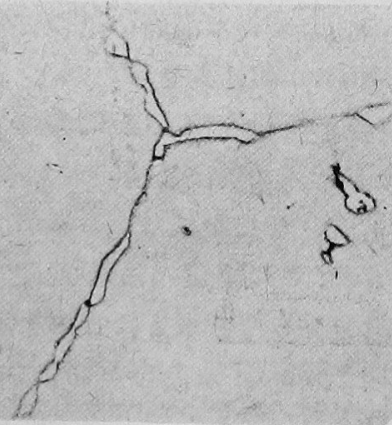

Photo. 11 Si $5.96 \%$ alloy, quenched after $G$ his. annealing at $600^{\circ}$

$\kappa+\gamma$ $\times 300$ 